\title{
Comprehensive Analysis on Economic Influence and Relation of China with Other Main Countries
}

\author{
Miao Zhi Fang, Xun Lu* \\ School of Computer Science \& Technology, Soochow University, Suzhou, China \\ Shizi Street No.1, 158\#, Suzhou, Jiangsu, China, 215006 \\ Email: 1227402013@suda.edu.cn, luxun@suda.edu.cn
}

Keywords: WTO;Trade; Influence; Economic; Political

\begin{abstract}
Contact tightness in today's diverse blend of modern society and its important significance, large national foreign policy and external activities, small business marketing and interpersonal, which virtually every corner of modern society. This article aims to study the world's main close ties to the country's economic and political ties, comprehensive measure of China's international influence, thereby more accurately, but also to many of its advantages and disadvantages.
\end{abstract}

\section{Introduction}

Now young people are divided over the international status of China, partial vision, too much emphasis on China's total GDP, also a pessimistic view that some view China, that China's economic development, lack of quality and sustainability. In order to reflect China's international status, select "close economic ties" and "close political ties," exploring China's real economic weight and political influence of the two indicators. This research theme of "tightness of major countries in the world economy and political affinity among research and analysis", here to use economic and political influence to a simple description.

For this indirect influence on the process, to the indirect effects of economic links here to make a statement: for example, a, b, c trade ties among the three countries, in country a and country c, country a and country b, country b and country c, with bilateral trade reaching 10,8,6, respectively. Which a, country and c country of directly trade called directly effects, can directly meter into influence, and a, country through b country on c country of effects is called indirect effects, because here a, country and c country Zhijian only an indirect national b country, this indirect effects called first layer indirect effects, its calculation method is $(\mathrm{AB}+\mathrm{BC}) *$ weight 0.5 , if a, country and $\mathrm{c}$ country Zhijian exists two an indirect effects national b country and d country, is called second layer of indirect effects, second layer indirect effects calculation method for $(\mathrm{AB}+\mathrm{BC}+\mathrm{CD}) *$ weight of 0.25 . Close economic links between country a and country c would be: $\mathrm{AC}+0.5^{*}$ $(\mathrm{AB}+\mathrm{AC})=17$.

This amounts to an analysis of 14 countries, including China, the United States, Japan, Germany, France, United Kingdom, Italy, Canada, Russia, Argentina, Australia, Brazil, India and South Africa.

Taking into account the conditions and technical requirements and computation with indirect effects calculated levels increase exponentially increased dramatically, so the degree of close economic ties between the countries and political closely calculated to the second-level only indirect influence.

\section{The Analysis Based On The Indirect Effects Of China's Economic Clout}

The measure of economic power in the world, different scholars are difficult to fully see eye to eye. International Shang most common of world economic powers of standard, main is from economic total and international economic contact two a aspects to measure, a is to has huge of economy total, that domestic production total accounted for world production total of 5\% above, II is to has close of international economic contact, that foreign trade total accounted for world trade total of $5 \%$ 
above, national currency is international reserves currency, and accounted for world reserves total of 5\% above. "From the 2008 14th issue of the people's Forum" economic aggregates (mainly refers to GDP) reflect the scale of a country's economy as a whole, while international economic links reflecting the openness of a country's economy. 2013 world's GDP totaled US \$ 73.98 trillion United States 2013 GDP of us \$ 16.7997 trillion, ranking first; China's GDP of US \$ 9.1814 trillion, in second place. "IMF official data" which China's gross domestic product accounted for $12.4 \%$ of the gross world product, 2013 rose to 11 per cent of total world trade in goods in China.5\%, for the first time overtook "calculated according to the relevant year". Other than apart from it has yet to become an international reserve currency, two indicators were far beyond the standards of world economic powers. In some of these countries the currency as a reserve currency for several years, but "was not willing to speak out." "The people's Bank of China Governor Zhou xiaochuan said at the IMF World Bank annual meeting in the fall." From this we can see, China is already a member of the world economic powers. Previous data has shown that in 2013, China's total trade in goods has become the first in the world, because it is common practice to foreign trade volume as a measure of international economic links, according to the most common standard of China's international economic ties is the world first.

However the most commonly used measure of international economic links only the country's total foreign trade, total foreign trade is only the sum of bilateral trade volume, and does not take into account in addition to bilateral economic ties, used for ease of understanding this article economic impact should be interpreted. Illustrate this form of indirect economic impact: in country $\mathrm{a}$ and country $\mathrm{b}$ has trade with country $\mathrm{b}$ and country $\mathrm{c}$, also has trade, but for some reason, in country a and country $\mathrm{c}$ without bilateral trade ties, but $\mathrm{c}$ goods imported from country $\mathrm{b}$ need to state a to State b, exports of raw materials to production. Thus it can be seen, while in country a and country c has no direct trade, but still in country a and country c has the economic ties, we call the indirect economic impact. This study on bilateral trade in 14 major countries around the world, take this discussion on international economic clout, China has reached the world number one.

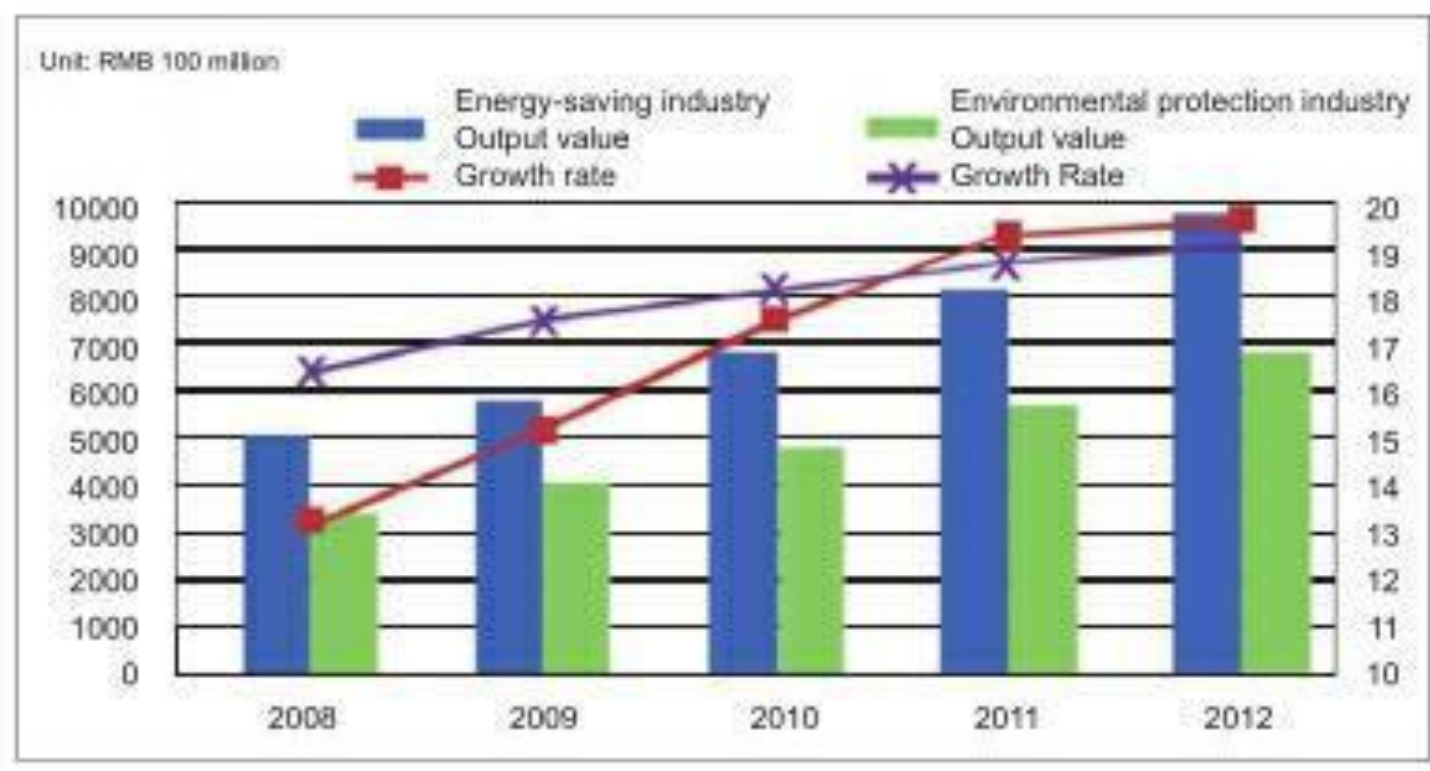

Fig 1 Energy-saving output and growth rates

\section{Based On The Analysis Of Direct Influence On The Political Clout Of China}

As indicated in the figure, combined with trade data found that China's foreign trade volume in 2012, more than United States and the gap in the 2013 continues to expand, growing from \$ 48.15 billion in 2012-2013-\$3142.9. Surface data from these analyses and economic impact seems to be starting in 2012, China has surpassed the United States in 2013 and is a gap has opened up, but these are preliminary data collected by the appearance of real economic influence is by no means as 
simple as only consider the total bilateral trade volume trade, should also take into account the indirect economic ties around the world. Thus in the introduction of indirect economic links after processing, we can find that China's economic influence in the last five years, no not beyond the United States. 2009-2013-United States average influence with China was 11.26 with 10.77, gap, while taking into account the structure of China's export products with the United States the gap of export products, China and the United States's economic influence gap remains large. The economic impact of research according to the final results from 14 countries are divided into 3 tier, the first Echelon for: United States, China; second-tier are: Japan, Germany, Canada and third Echelon are: France, United Kingdom, Italy, Russia, Australia, Brazil, India, South Africa and Argentina. China, Russia, Brazil, India, South Africa, Argentina's economic clout counts toward the 40\%, although it can be seen that the economies of developing countries say has been strong, but still holds control over traditional Western influence.

\section{CHINA'S IMPORTS AND EXPORTS IN 2012}

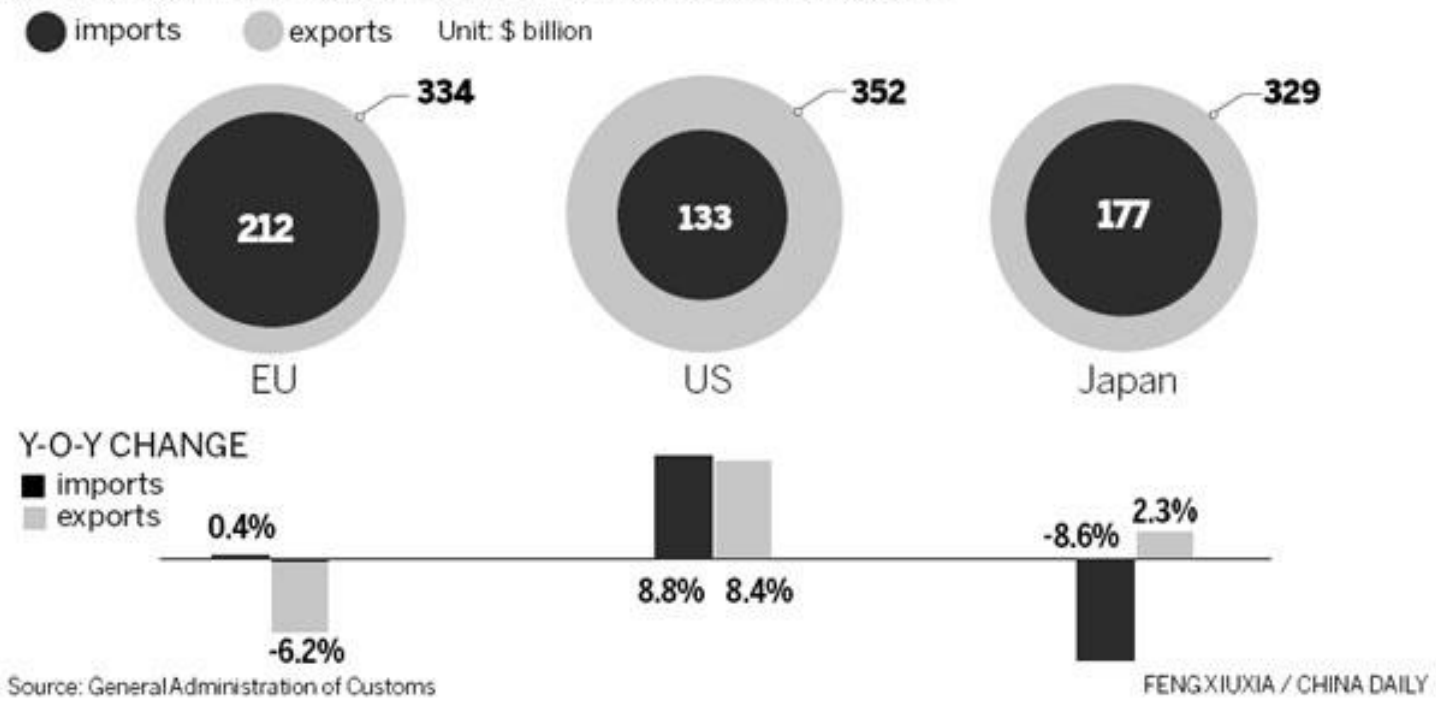

Fig 2 China's imports and exports in 2012

Make a bold speculation it may be based on the results, taking into account the end of China's economic reforms and the demographic dividend, economic uncertainty will increase, the 2013 world economy characterized by internal differentiation within developed and developing countries to expand, United States, and Europe and Japan is weak. So United States of economic growth still will continued, addition United States of page rock gas revolution and manufacturing revival plans of continued advance, speculated that Sino-US between of economic influence of peak in $11.5 \%$ around, which United States will in 2025 around can arrived $11.5 \%$, then entered stable fluctuations period, and China earlier of economic influence should in $11.2 \%$ around, China economic influence is expected to will in 2050 years around reached peak, and United States par. Of course, every country's rise is accompanied by a comprehensive series of games, China's road to recovery was still difficult. 


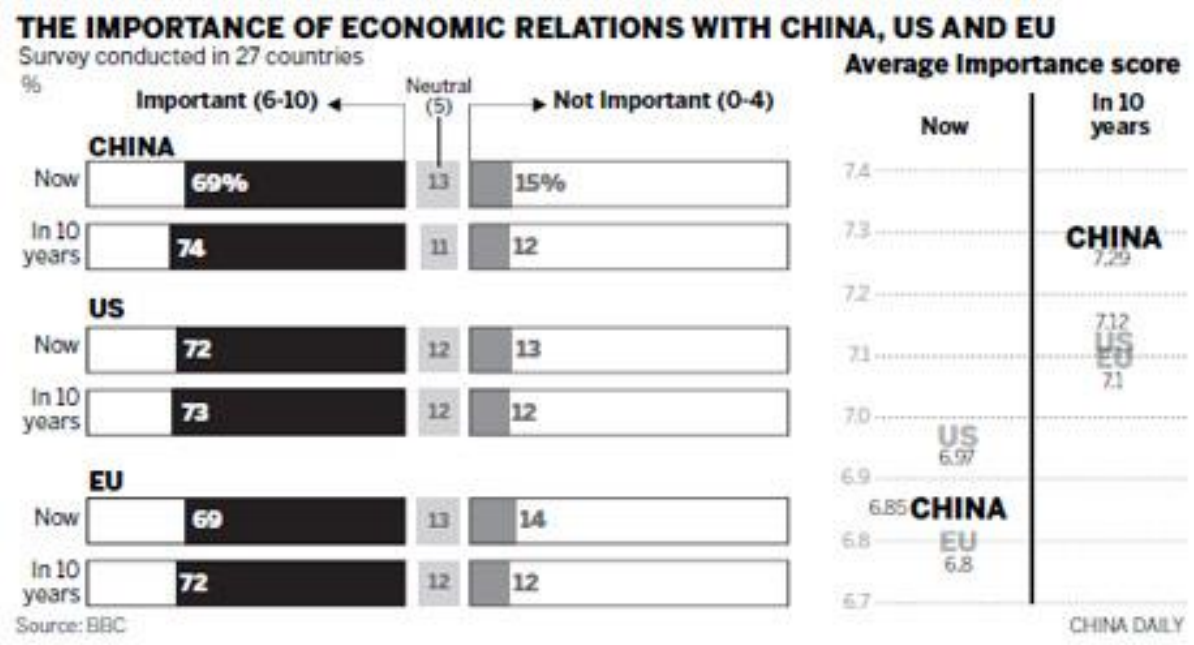

Fig 3 the importance of economic relation with China

\section{Based On The Analysis Of Indirect Influence On The Political Clout Of China}

Below is a screenshot of political influence, political influence on the processing and analysis of data for both engines was the new head of State's first visit to the country by access orders, number of joint military exercises this year, and whether to establish diplomatic relations at ambassadorial level as well as the heads of State of the following above the provincial level officials visited each other frequently.

We can see in the following figure, relatively large fluctuations of political influence, political clout can be ranked in the first tier of countries are: United States, China, Japan, remaining of which are volatile, Echelon will not do the assignment. 


\section{CHART 1: COMPARISON OF THE RATINGS OF MA JOR CREDITOR AND DEBTOR COUNTRIES BY S\&P BEFORE AND AFTER THE CREDIT CRISIS (LOCAL CURRENCY)}

\begin{tabular}{|c|c|c|c|c|c|c|}
\hline No. & $\begin{array}{l}\text { Developed debtor } \\
\text { country }\end{array}$ & 2006 & 2010 & $\begin{array}{l}\text { Emerging creditor } \\
\text { country and region }\end{array}$ & 2006 & 2010 \\
\hline 1 & The US & AMA & $\mathrm{MA}$ & China & A & At \\
\hline 2 & Japan & AA- & AA & Russia & A & $868+$ \\
\hline 3 & Germany & AAA & MA & Saudi Arabia & At & A. \\
\hline 4 & France & AAA & MA & Tawan, China & A. & A. \\
\hline 5 & The UK & $\overline{A A A}$ & $\mathrm{MA}$ & Hong Kong, China & $\overline{\mathrm{A}}$ & $\mathrm{AAt}$ \\
\hline 6 & Italy & At & At & Intia & $B 8+$ & BB:- \\
\hline 7 & Spain & AAA & AA & South Korea & At & At \\
\hline 8 & Austria & AAA & $\mathrm{MA}$ & Brazil & $B 8+$ & $B B B+$ \\
\hline 9 & Belgium & $\overline{A A+}$ & $\mathrm{AA+}$ & Thaland & $A$ & $A$ \\
\hline 10 & Portugal & AA. & A & Indonesia & $\mathrm{BB+}$ & $\mathrm{BB}+$ \\
\hline II & Ineland & $\overline{A A A}$ & $\mathrm{~A}$ & Shoapere & AMA & MAA \\
\hline 12 & Greace & A & $88+$ & Malaysia & A+ & At \\
\hline 13 & keland & AA & $B 6 B$ & Argentina & B+ & 8 \\
\hline 14 & Canada & AAA & AAA & Algeria & & \\
\hline 15 & The Netheriands & AAA & $\mathrm{MA}$ & $\operatorname{Iran}$ & & \\
\hline
\end{tabular}

Mote: sap has not ratedAlzetla and kn.

\section{CHART 2: THE ADJUSTMENT BY THREE US RATING AGENCIES FOLLOWING DAGONG RATINGS (LOCAL CURRENCY)}

\begin{tabular}{|c|c|c|c|c|c|}
\hline \multirow[b]{2}{*}{ Country/region } & \multicolumn{2}{|c|}{ Dagong } & \multicolumn{3}{|c|}{ Adjustments by three agencies } \\
\hline & $\begin{array}{l}\text { Rating } \\
\text { grade }\end{array}$ & $\begin{array}{l}\text { Rating } \\
\text { time }\end{array}$ & Rating grade change & $\begin{array}{l}\text { Time of } \\
\text { adjustment }\end{array}$ & Agency \\
\hline Argertina & B & 2010.07 .11 & Upgrading to B from B. & 2010.07 .12 & Fitch \\
\hline Portugal & A & 201007.11 & Downgrading to A1 from A12 & 2010.07 .13 & Moody's \\
\hline Estonia & A & 2010.07 .11 & Upgrading to A from BBB+ & 2010.07 .19 & Fitch \\
\hline India & BBB & 2010.07 .11 & Upgrading to Bal from Ba2 & 2010.0726 & Moody's \\
\hline Ireland & & 2010.07 .11 & $\begin{array}{l}\text { Downgrading the outbok to } \\
\text { negative from stable }\end{array}$ & 2010.0730 & Moody's \\
\hline Russia & Astable & 201007.11 & $\begin{array}{l}\text { Upgrading the outbokto } \\
\text { positive from stable }\end{array}$ & 2010.09 .08 & Fitch \\
\hline Argertina & B & 2010.07 .11 & Upgrading to B from B. & 2010.09 .13 & S\& P \\
\hline Spain & A & 201007.11 & Downgrading to Aaa from Aal & 2010.0930 & Moody's \\
\hline $\begin{array}{l}\text { Hosg Kong, } \\
\text { China }\end{array}$ & AM & 2010.10 .21 & Upgrading to Aal from Aa2 & 2010.11 .11 & Moody's \\
\hline China & $A A+$ & 2010.07 .11 & Upgrading to Aas from $A 1$ & 2010.11 .13 & Moody's \\
\hline Ireland & BBB & 2010.12 .06 & Downgrading to $B B B+$ from $A+$ & 2010.12 .09 & Fitch \\
\hline Ieeland & BB8 & 201012.06 & Downgrading to $B B B+$ from $A A$ & 2010.12 .20 & Moody's \\
\hline
\end{tabular}

Fig 4. Scores of the ratings of Major Creditor and debtor countries

Comprehensive analysis of the economic weight and political influence can be seen, and political influence of China and the United States compared with the economic impact of the gap is wider, China's economy has overtaken Japan, but political clout is not Japan opened the obvious gaps, and the last five years showed a downward trend. Which reflects China's lack of ability to go outside there, should focus on the country's image and cultural construction, and strive to enhance the soft power. Strengthening the construction of diplomatic and build a stable and peaceful environment for economic development.

\section{Conclusion}

After decades of rapid development, China, 2013-although the total external trade in goods has become the first in the world, but the real economic clout, China is still behind the United States. Political influence in China and the United States gap compared with greater economic clout, so we can see United States first in the world the position remained unchallenged in the short term. But compared to other countries, China's advantage is more obvious influence. 


\section{Acknowledgements}

Miaozhi Fang, student ID Number: 1227402013, currently is an undergraduate student of Computer Science and Technology School of Soochow University. This work was directed by Xun Lu.

\section{References}

[1] Rose A K. Do we really know that the WTO increases trade[R]. National bureau of economic research, 2002.

[2] Bello J H. The WTO dispute settlement understanding: less is more[J]. American Journal of International Law, 1996: 416-418.

[3] Lindemann B A. Case Study 1: The World Trade Organization (WTO)[M]//Cross-Strait Relations and International Organizations. Springer Fachmedien Wiesbaden, 2014: 95-160.

[4] Bown C P. Trade Policy Flexibilities and Turkey: Tariffs, Anti-dumping, Safeguards and WTO Dispute Settlement[J]. The World Economy, 2014, 37(2): 193-218.

[5] Wang C, Wan G, Yang D. Income Inequality In The People'S Republic Of China: Trends, Determinants, And Proposed Remedies[J]. Journal of Economic Surveys, 2014, 28(4): 686-708.

[6] Xie Y, Zhou X. Income inequality in today's China[J]. Proceedings of the National Academy of Sciences, 2014, 111(19): 6928-6933.

[7] Sznajder K K, Harlow S D, Burgard S A, et al. Urogenital infection symptoms and occupational stress among women working in export production factories in Tianjin, China[J]. Asian Pacific Journal of Reproduction, 2014, 3(2): 142-149.

[8] Global trade analysis: modeling and applications [M]. Cambridge university press, 1998.

[9] Zhi Y, Luo C. Export Competition in China: Evidence from Data at Provincial Level[J]. Fudan Journal of the Humanities and Social Sciences, 2014: 1-18.

[10] Gao Y, Whalley J, Ren Y. Decomposing China's export growth into extensive margin, export quality and quantity effects[J]. China Economic Review, 2014, 29: 19-26.

[11] Gleditsch K S. Expanded trade and GDP data [J]. Journal of Conflict Resolution, 2002, 46(5): 712-724.

[12] Kwan C H. Comment on "China's Economic Influence in Latin America"[J]. Asian Economic Policy Review, 2014, 9(2): 225-226.

[13] Cansino J M, Cardenete M A, González-Limón J M, et al. The economic influence of photovoltaic technology on electricity generation: A CGE (computable general equilibrium) approach for the Andalusian case[J]. Energy, 2014, 73: 70-79.

[14] Kowalczyk R, Górny M, Schmidt K. Edge effect and influence of economic growth on Eurasian lynx mortality in the Białowieża Primeval Forest, Poland[J]. Mammal Research, 2014: 1-6.

[15] Brons M D A, Liefbroer A C A, Ganzeboom H B G H. The influence of parental socio-economic status on the timing of first union across European countries[J]. 2014.

[16] Stevens P. The 'Shale Gas Revolution': Hype and Reality [M]. London: Chatham House, 2010.

[17] Urbanos-Garrido R M, Lopez-Valcarcel B G. The influence of the economic crisis on the association between unemployment and health: an empirical analysis for Spain[J]. The European Journal of Health Economics, 2014: $1-10$.

[18] Radebaugh L H. Environmental factors influencing the development of accounting objectives, standards and practices in Peru[J]. The international Journal of Accounting Education and Research. Urbana, 2014, 11(1): 39-56. 